Biografistyka Pedagogiczna

Rok 2 (2017) nr 1

ISSN 2543-6112; e-ISSN 2543-7399

DOI: $10.36578 /$ BP.2017.02.21

\title{
Tomasz Janusz Wach (1961-2016) - biogram i wspomnienia pracowników oraz studentów Instytutu Pedagogiki KUL
}

Tomasz Janusz Wach (1961-2016) - A Biographical Note and

Memories of Employees and Students of the Institute of Pedagogy, The John Paul II Catholic University of Lublin (KUL)

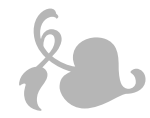

\section{Biogram}

Tomasz Wach, urodził się 13 kwietnia $1961 \mathrm{r}$. w Lublinie, zmarł 28 grudnia 2016 r. w Lublinie, dr hab., adiunkt w Katedrze Pedagogiki Opiekuńczej i Pedagogiki Społecznej.

Był synem Józefa i Jadwigi z domu Depta. W 1976 r. ukończył szkołę podstawową nr 3 w Lublinie, następnie w 1982 r. Technikum Energetyczne na ul. Długosza w Lublinie. W 1987 r. został magistrem pedagogiki opiekuńczo-wychowawczej na Uniwersytecie Marii Curie-Skłodowskiej w Lublinie na podstawie pracy Plany życiowe nieletnich niedostosowanych społecznie, której promotorem był prof. Stanisław Kosiński (dodatkowo odbył studia podyplomowe z zakresu resocjalizacji i administracji oświatowej). 3 grudnia 1997 r. został doktorem nauk humanistycznych $\mathrm{w}$ zakresie socjologii na UMCS, przygotowując

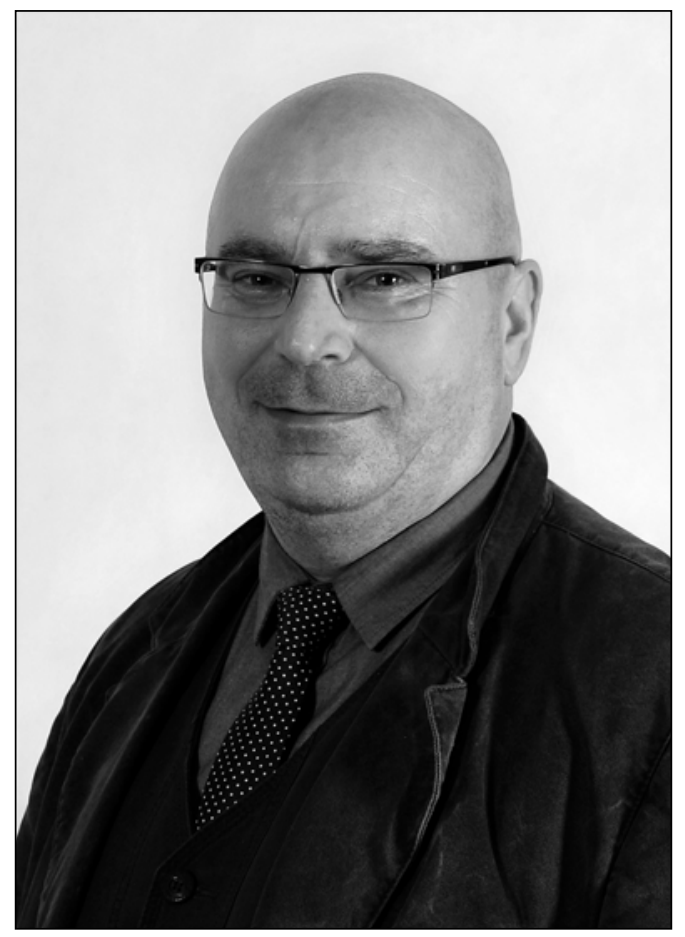

Fotografia: Witold Cegiełka 
na Wydziale Filozofii i Socjologii pod kierunkiem prof. Mariana Filipiaka pracę pt. Osobowość społeczna abiturientów wybranych szkół podstawowych miasta Lublina. 17 maja 2007 r. obronił drugi doktorat - tym razem z nauk humanistycznych w zakresie pedagogiki na Katolickim Uniwersytecie Lubelskim Jana Pawła II, przygotowany pod kierunkiem ks. prof. Mariana Nowaka pt. Możliwości resocjalizacji nieletnich sprawców gwattownych czynów zabronionych. 21 grudnia 2016 r. Rada Wydziału Akademii Pedagogiki Specjalnej im. Marii Grzegorzewskiej w Warszawie zatwierdziła jego habilitację na podstawie dysertacji Profilaktyka i resocjalizacja nieletnich zagrożonych uzależnieniem od środków psychoaktywnych, Warszawa 2014, tym samym uzyskał on tytuł dra hab. w zakresie pedagogiki - pedagogika resocjalizacyjna.

Odbył dodatkowe kursy i szkolenia: Studium Podyplomowe z Zakresu Organizacji i Zarządzania (Warszawa SGH); Studium Przeciwdziałania Przemocy (Warszawa - Instytut Psychologii Zdrowia); Warsztaty nt. Mediacji Między Ofiarą a Sprawcą organizowane przez Senat RP; uprawniony mediator sądowy - lista Sądu Okręgowego (i Sądu Apelacyjnego) w Lublinie. Został wpisany na listę biegłych sądowych z zakresu socjologii i pedagogiki resocjalizacyjnej - w okresie 2003-2009 opracował ok. 300 opinii diagnostycznych dla sądów powszechnych (Wydziałów Rodzinnych i Nieletnich oraz Karnych Sądów Rejonowych).

W latach 1986-1987 pracował jako wychowawca w Bursie Szkolnictwa Zawodowego Nr 1 w Lublinie; w latach 1988-1992 pracował na stanowisku pedagoga szkolnego w Szkole Podstawowej Nr 46 w Lublinie; w latach 1987-1992 był kuratorem społecznym w Wydziale V Rodzinnym i Nieletnich Sądu Rejonowego w Lublinie; od 1992 r. został zatrudniony w Schronisku dla Nieletnich w Dominowie jako: kierownik internatu (1992-1994), zastępca dyrektora (1994), dyrektor (1995-2003), pedagog w zespole diagnostycznym (2003-2016); w latach 1993-1994 oraz w 1998 r. był Pełnomocnikiem Wojewody Lubelskiego ds. Profilaktyki i Rozwiązywania Problemów Alkoholowych; od marca 2004 r. był kuratorem społeczny dla dorosłych w Sądzie Rejonowym w Lublinie; od $2006 \mathrm{r}$. pracował na umowę zlecenie na KUL, a od 1 października $2011 \mathrm{r}$. był zatrudniony jako adiunkt w Katedrze Pedagogiki Ogólnej (do 30 września 2013 r.), następnie w Katedrze Pedagogiki Opiekuńczej przemianowanej na Katedrę Pedagogiki Opiekuńczej i Pedagogiki Społecznej.

Tomasz Wach skupiał się na następującej działalności szkoleniowej: przez pięć pierwszych edycji instruktor programu „7 kroków”; organizacja szkoleń 
z zakresu profilaktyki uzależnień oraz przemocy w rodzinie w ramach Wojewódzkiego Programu Profilaktyki i Rozwiązywania Problemów Alkoholowych; współpracował z: Wszechnicą Świętokrzyską w Kielcach (1998-2002 - promotor 97 obronionych prac licencjackich); Wyższą Szkołą Humanistyczno-Przyrodniczą w Sandomierzu (2003-2016 - promotor kilkudziesięciu prac dyplomowych na podyplomowych studiach z zakresu resocjalizacji); Akademią Humanistyczno-Ekonomiczną w Łodzi (2006-2011); National Louis University w Nowym Sączu (2009-2011); Centrum Metodycznym Pomocy Psychologicznej w Warszawie - realizacja szkoleń dla grup profesjonalnych z zakresu przeciwdziałania przestępczości, profilaktyki uzależnień, tworzenia systemów pomagania. Był moderatorem przy szkoleniach dla kadry kierowniczej placówek resocjalizacyjnych; współpracował z Kuratorium Oświaty w Lublinie i Centrum Doskonalenia Nauczycieli w Puławach przy szkoleniu edukatorów (według programu MENis).

Dr hab. Tomasz Wach był wybitnym znawcą problemów przestępczości nieletnich, przemocy i uzależnień (od alkoholu oraz innych środków psychoaktywnych); systemów współpracy instytucji i międzyinstytucjonalnych systemów pomagania; przemocy, w tym rodzinnej; bezpieczeństwa pracowników w trakcie wykonywania czynności zawodowych; mediacji, negocjacji, w tym w sytuacji konfliktu; subkultur młodzieżowych; wykluczenia społecznego, marginalizacji jako tła zachowań przestępnych. Był wysokiej klasy praktykiem, który działalność praktyczną łączył z prowadzonymi badaniami i rozważaniami naukowymi w wymienionych dziedzinach.

Jest autorem wielu publikacji, w tym wartościowych w pedagogice resocjalizacyjnej dwóch monografii: Resocjalizacja nieletnich sprawców gwałtownych czynów zabronionych, Lublin 2009; Profilaktyka i resocjalizacja nieletnich zagrożonych uzależnieniem od środków psychoaktywnych, Warszawa 2014; książek pod redakcją: Wzory i wzorce osobowe $w$ biografistyce pedagogicznej, red. R. Skrzyniarz, M. Gajderowicz, T. Wach, Lublin 2013; oraz licznych artykułów w czasopismach i pracach zbiorowych oraz haseł encyklopedycznych i słownikowych. Kierował i brał udział w grantach i projektach badawczych. Czynnie uczestniczył w konferencjach międzynarodowych i krajowych.

Był członkiem Towarzystwa Wiedzy Powszechnej (Oddz. w Lublinie) od 2002 r., w latach 1999-2003 był ekspertem MEN w Komisjach ds. Awansu Zawodowego Nauczycieli. Od kilku lat działał w: Polskim Towarzystwie Psychologicznym od 2005 r., Zespole Pedagogiki Chrześcijańskiej pod 
patronatem Komitetu Nauk Pedagogicznych PAN (był członkiem założycielem), Zespole Pedagogiki Społecznej przy KNP PAN od 2015 r. Dwukrotnie był nagradzany przez Ministra Sprawiedliwości za swoją pracę w Schronisku dla Nieletnich w Dominowie, otrzymał Medal Komisji Edukacji Narodowej, dwanaście nagród Prezesa Sadu Okręgowego w Lublinie. Odbył dwa staże zagraniczne, pełnił rolę biegłego sadowego z zakresu pedagogiki resocjalizacyjnej.

Pogrzeb śp. dra hab. Tomasza Wacha odbył się 4 stycznia 2017 r. o godz. 12.00 w kościele św. Agnieszki w Lublinie. Ciało zostało złożone do rodzinnego grobowca na cmentarzu parafialnym na Kalinowszczyźnie w 14. sektorze. W uroczystościach pogrzebowych wzięły udział władze KUL: prorektor ds. studenckich ks. prof. Andrzej Kiciński, dziekan wNs ks. prof. Stanisław Fel oraz prodziekani prof. Ewa Domagała-Zyśk i prof. Elżbieta Rydz, dyrektor Instytutu Pedagogiki ks. prof. Marian Nowak oraz przedstawiciele władz innych uczelni, z którymi Tomasz Wach współpracował. Licznie przybyli obecni i emerytowani pracownicy oraz studenci i absolwenci Instytutu Pedagogiki KUL, przedstawiciele zakładów penitencjarnych, z którymi zmarły współdziałał, rodzina i znajomi. W koncelebrze mszy św. za duszę śp. Tomasza Wacha wzięło udział trzynastu duchownych.

\section{Bibliografia}

Tomasz Wach (1961-2016), teczka osobowa, Dział Spraw Personalnych KUL; Biogram opracowano na podstawie materiałów habilitacyjnych APS im. M. Grzegorzewskiej w Warszawie, http://wnp.aps.edu.pl/habilitacje-i-profesury/przebiegpost $\%$ C4\%99powa\% $\%$ 5\%84-habilitacyjnych-nowy-tryb.aspx, dostęp: 1.02.2016; B. Śliwerski, Niespodziewana śmierć pedagoga resocjalizacji dr hab. Tomasza Wacha, adiunkta KUL, http://sliwerski-pedagog.blogspot.com/2016/12/niespodzierwana-smierc-pedagoga.html, dostęp: 1.02.2016; R. Skrzyniarz, Pożegnanie Tomasza Wacha, „Przegląd Uniwersytecki”, 29 (2017) 1 (165) s. 39-40.

\section{Wspomnienia o drze hab. Tomaszu Wachu}

Wystąpiłem z prośbą do pracowników i studentów pedagogiki KUL o napisanie wspomnień o Tomaszu Wachu, argumentując to tym, iż: „pragnę zachować dla kolejnych pokoleń studentów i pracowników KUL postać śp. dra hab. Tomasza Wacha, dlatego planuję zebrać Państwa wspomnienia o Nim. Mogą to być krót- 
kie, kilkuzdaniowe opowieści o tym, jak Go Państwo pamiętacie i wspominacie. Mam nadzieję, że zebrane wspomnienia ukażą wielopłaszczyznowy portret wszechstronnego pedagoga, który przedstawię w czasopiśmie biograficznym". Zamieszczam zatem zebrane wspomnienia pracowników oraz studentów Instytutu Pedagogiki KUL, którzy przesłali je na mojego maila lub Facebooka. Nie ingerowałem w treść nadesłanych wspomnień, jedynie uściślenia lub sprostowania zaznaczyłem w nawiasach kwadratowych.

\section{Pracownicy Instytutu Pedagogiki}

\section{No, kto jak nie my?}

Z Tomkiem współpracowałam kilkakrotnie w zespołach tworzących i realizujących projekty edukacyjne, najpierw było to „Kompetentne wsparcie”, czyli cykl szkoleń dla nauczycieli w zakresie pracy z uczniami ze specjalnymi potrzebami edukacyjnymi, potem cykl warsztatów dotyczących niepełnosprawności i izolacji więziennej, a w okresie październik-grudzień 2016 r. - projekt aplikacji studiów podyplomowych w zakresie doskonalenia kompetencji wychowawczych nauczycieli. Zaczęliśmy także prace nad podręcznikiem dotyczącym tego zagadnienia, a ostatni mail otrzymany od Tomka w tej kwestii - wraz z życzeniami świątecznymi („Życzę Ci wszelkiej pomyślności (tak Ci życzę nie tylko przy okazji świąt... Tomek”) - nosi datę 21.12 i ciągle jest w folderze „Odebrane” mojej poczty.

Tomek był znakomitym współpracownikiem. Twórczym, szukającym nowych rozwiązań, akceptującym zarówno ograniczenia związane z projektami, jak i otwartym na wnoszenie zmian, choćby nawet wymagało to dodatkowej pracy. Był osobą niezwykle kompetentną w zakresie niedostosowania społecznego i zagrożenia niedostosowaniem - precyzyjny w zakresie stosowania terminologii, oczytany w literaturze, z dużym doświadczeniem praktycznym. Jednocześnie niestwarzającym dystansu i niepogardzającym tymi, którzy na niedostosowaniu znali się znacznie mniej niż on.

Jego śmierć - jak to śmierć - przyszła w najmniej oczekiwanym momencie, w trakcie pracy nad koncepcją książki przygotowywaną przez zespół zaangażowany w projekt dotyczący kompetencji wychowawczych nauczycieli. W mailu z 4 listopada 2016 r. Tomek pisał: 
Cześć

bardzo uprzejmie zwracam uwagę, że do tej pory NIKT nie napisał jednolitego podręcznika metodycznego do pracy z uczniami wymagającymi wsparcia rozwojowego ukierunkowanego korekcyjnie, czyli np. resocjalizacyjnie. Tzn. są takie starocia albo opracowania cząstkowe.

A może tak:

Kompetencje wychowawcze: wychowanie - profilaktyka - resocjalizacja praca socjalna. Wiele aspektów, systemowość, aplikacyjność.

Jakby temat stał się bardziej aktualny - ja wchodzę!!!

Zaś kilka dni później dodawał (w mailu z 23 listopada 2016 r.)

Witaj,

Ja jestem gotowy napisać rozdział odnoszący się tematycznie do „moich przedmiotów”, ale też mogę wziąć udział w czymś szerszym. To zależy od podejścia do całości.

Jeśli celem byłby podręcznik metodyczny - chyba lepiej potraktować sprawę konkretnie i napisać coś zawierającego wskazówki do pracy, może nawet konkretne przykłady programów, zajęć.

Jeśli opracowanie miałoby mięć charakter pełniejszej monografii - także proszę mnie brać pod uwagę, wtedy napiszę rozdział dotyczący np. podejścia systemowego do planowania pracy wychowawczej, w tym w sytuacjach obciążeń rozwojowych.

W każdym przypadku mogę się włączać, oczywiście trzeba wybrać opcję... Pozdrowienia - T.

W każdym kolejnym z kilkudziesięciu maili dotyczących aplikacji projektowej dosyłał materiały, sugestie dotyczące kadry, wskazówki do tworzenia programu, tak, jak na przykład ta z 23 listopada 2016 r.:

Przy okazji moja uwaga nt. zaliczeń. Otóż wydaje się uzasadnione, by uczestnicy mogli opracowywać projekt (identyfikacja jakiegoś problemu wychowawczego dla nich istotnego, opracowanie programu oddziaływań zmieniającego stan rzeczy oraz kryteria oceny skuteczności). Takie coś, co piszą nasi studenci. My mamy wtedy poważny argument aplikacyjny, ale i uczestnicy mają coś konkretnego. Oczywiście jeden projekt na grupę przedmiotów. Z dużą swobodą dla kursantów, choć z zachowaniem formy projektu. 
Śmierć Tomka oznacza jednak wielki brak - jego pewności siebie i poczucia bezpieczeństwa, które dawał. Jego wiedzy i wytrwałości. Poczucia humoru i dystansu. Mimo chwilowej przerwy w pracy nad tym projektem - mam nadzieję, że wrócimy do niego, wszak Tomek wielokrotnie zagrzewał nas do pracy słowami: „No, kto, jak nie my??”.

Niekiedy mówimy na uczelni, że prawdziwe życie zaczyna się po habilitacji. I teraz stamtąd, gdzie jesteś - tak właśnie do nas mówisz, mrużąc oczy: „A nie mówiłem - prawdziwe życie zaczyna się po habilitacji".

dr hab. Ewa Domagała-Zyśk, prof. KUL, prodziekan ds. nauki i kontaktów międzynarodowych WNS

\section{U. Ulotność spotkania i pożegnanie słowami „do zobaczenia”}

Pana dr hab. Tomasza Wacha poznałam wiele lat temu, kiedy wraz ze mną uczestniczył w zebraniach Instytutu Pedagogiki przeznaczonych dla młodszych pracowników naukowych. Pamiętam Go z tych czasów jako bardzo serdecznego i miłego Kolegę. Zapewne dla niejednej osoby stykającej się w pracy $\mathrm{z}$ dr Tomaszem dopiero habilitacyjne lub pośmiertne curriculum vitae ukazało Jego postać jako wybitnego naukowca, praktyka i działacza na polu pedagogiki resocjalizacyjnej. Skromność, prostota, pokora - to cechy, które skrywały człowieka o wielkiej wiedzy i oddaniu sprawom społecznym, nieafiszującego się swoimi osiągnięciami.

Od czasu, kiedy w 2014 r. zaczęłam sprawować funkcję kierownika Katedry Psychopedagogiki sąsiadującej z Katedrą Pedagogiki Opiekuńczo-Wychowawczej i Resocjalizacyjnej [wówczas Katedra Pedagogiki Opiekuńczej, obecnie Katedra Pedagogiki Społecznej i Pedagogiki Opiekuńczej], nasze spotkania stały się częstsze, gdyż nieraz w drodze na zajęciach lub jeszcze lepiej - po nich, mieliśmy czas, aby na korytarzu zamienić parę zdań na temat naszego samopoczucia, bieżących spraw instytutowych, pracy ze studentami, uciążliwości zajmowania się „zbieractwem” punktów na kolejny stopień naukowy i trapiącym pracowników schorzeniem zwanym „punktozą". Bardzo rozumieliśmy się w tym, jak pracować solidnie i nie dać się powalić tej zaraźliwej uczelnianej chorobie. Niezależnie od treści tych korytarzowych rozmów, zawsze kończyły się one pozytywnym akcentem, rozchodziliśmy się do naszych obowiązków 
z nową werwą, podniesieni na duchu koleżeńskim spotkaniem. A czasem, gdy nie było okazji do przystanięcia - wymiana uśmiechu i gestu wystarczyła, aby poczuć wspólnotę ducha.

Kiedy zainicjowałam zorganizowanie sesji naukowej nt. „Zagrożenia i szanse dla «dzieci ulicy»" (15 kwietnia 2015) przez naszą Katedrę Psychopedagogiki wraz z Katedrą Pedagogiki Opiekuńczo-Wychowawczej i Resocjalizacyjnej, w której dr Tomasz Wach pracował, Pan Doktor chętnie przychylił się do uczestnictwa i wygłosił bardzo interesujący wykład nt. „Czy «dzieci ulicy» to problem realny?". Dokonał wtedy precyzyjnego rozróżnienia między terminami stosowanym w pedagogice resocjalizacyjnej i omówił rodzaje ich błędnego stosowania. Był to analityczny i jasny wywód, wskazujący na ogromną erudycję w podjętym temacie. Czuło się profesjonalistę i chociaż sesja nie była planowana na duże audytorium, przygotował się do tego po mistrzowsku. Innym razem wyraził zgodę na poprowadzenie warsztatu o zagrożeniach tatuażu jako młodzieżowej mody, w odpowiedzi na przekazaną Mu przeze mnie prośbę ze środowiska warszawskiego. Po tym wspólnym przedsięwzięciu konferencyjnym nt. „dzieci ulicy” kilka razy rozmawialiśmy o planie wydania wspólnej książki online na temat psychopedagogicznych aspektów wykluczenia społecznego dzieci i młodzieży zagrożonej oraz form profilaktyki i pomocy im. Niestety nasze inne zaangażowania i odłożenie pomysłu na później (to zmora współczesnych nam czasów) nie doprowadziły do konkretyzacji i sfinalizowania tego pomysłu. Jakże nieprawdziwe okazało się przysłowie: „Co się odwlecze, to nie uciecze". Uciekło bezpowrotnie...

Pisząc to krótkie wspomnienie o koledze Tomaszu Wachu, trudno nie wspomnieć o tym, że był bardzo dobrym mężem i ojcem. Ze swoją żoną Jolantą Latowską-Wach, psychologiem klinicznym i psychoterapeutą, pracującą w Specjalistycznej Poradni Psychoprofilaktyki i Terapii Rodzin im. Włodzimierza Fijałkowskiego w Lublinie stworzyli ciepły dom, w którym mogła wzrastać ukochana córka Kinga [Inga]. Tomasz był dla Niej prawdziwym przyjacielem, aktywnie włączał się w proces Jej wychowania. Już po pogrzebie dowiedziałam się, że z okazji Jej poczęcia, otrzymali w prezencie od dyrektor poradni, w której pani Jola pracowała - mgr Gryżyny Soszyńskiej - moją książkę Oblicza macierzyństwa. Nie znaliśmy się jeszcze z Panem Profesorem, a już nasze drogi w ten sposób połączyły się na styku życia rodzinnego i naukowego. Gdyby nie ten 
szczęśliwy dom, nasz Kolega nie mógłby tak intensywnie pracować i tak wiele osiągnąć. Na zapleczu Jego zaangażowań naukowych, dydaktycznych i społecznych była Żona, z oddaniem dbająca o to, by dom był gniazdem rodzinnym, do którego z utęsknieniem wracał i nabierał sił do pracy. Pani Jolu - dziękujemy!

Szczególne miejsce w sercu Tomasza Wacha zajmowała również jego mama Pani Jadwiga Wach, która wychowywała go po wczesnej śmierci ojca. O mamie zawsze mówił z atencją i miłością. Interesował się Nią na co dzień, a w sytuacjach trudniejszych był dla niej wielką pomocą. Pani Jadwiga była dumna z syna i gorąco omodlała Jego życie rodzinne i zawodowe, również wtedy, gdy pielgrzymowała do lokalnych sanktuariów, jak również na Jasną Górę oraz do Łagiewnik. W Grupie Modlitewnej Ojca Pio Pani Jadwiga nazywana jest „Słoneczkiem”. To Ona - Słoneczko dała Mu „korzenie i skrzydła”, przekazała mądrość życiową, dzięki czemu wyposażony był w kompas ukazujący, co jest w życiu najważniejsze i jaką drogą warto kroczyć przez życie. Pani Jadwigo dziękujemy!

Kiedy w środę 21 grudnia w Sekretariacie Instytutu spotkałam Pana Tomasza już od dwóch dni habilitowanego - był rozpromieniony, radosny. Chociaż zawsze był postawny, wtedy wydawał się jeszcze większy, sprężyście wyprostowany. Przyjmował od nas gratulacje, serdeczne uściski i życzenia. Było nas kilka osób, częstujących się instytutową Wigilią, przygotowaną wedle tradycji przez dyrektora ks. prof. dr hab. Mariana Nowaka. Składając życzenia Panu Tomaszowi na "dalszą drogę życia", nie wiedziałam, że chodzi o inną już drogę... Wyraziłam wtedy radość, że tak solidni i prawi pracownicy naukowi, jak On, zastąpią nasze odchodzące powoli z uczelni pokolenie osób tworzących Instytut Pedagogiki od jego początku i będzie można mieć pewność, że idee katolickiego uniwersytetu (a nie szkoły wyższej) będą w Instytucie kontynuowane i rozwijane.

Minęło kilka świątecznych dni i... szok, niedowierzanie, smutek, żal, uzmysłowienie sobie kolejny już raz prawdziwości słów ks. Jana Twardowskiego: „Spieszmy się kochać ludzi, tak szybko odchodząa". Wypowiedziane na pożegnanie z panem Tomkiem słowa "do zobaczenia" nabrały eschatologicznego sensu. Teraz przychodzi już tylko prosić naszego Kolegę, aby czuwał nam nami, nad Instytutem Pedagogiki, abyśmy mogli zobaczyć się kiedyś z Nim.

dr hab. Dorota Kornas-Biela, prof. KUL, kierownik Katedry Psychopedagogiki 


\section{Rzetelny profesjonalista, dobry kolega, mądry nauczyciel}

Tomasza Wacha poznałam z chwilą jego zatrudnienia w Instytucie Pedagogiki KUL. Wcześniej słyszałam wiele dobrego o jego profesjonalizmie i dużym doświadczeniu w pracy wychowawczej z młodzieżą niedostosowaną społecznie, od kolegi z Katedry. W ciągu dziesięciu lat wspólnej pracy na KUL-u przekonałam się, że nie ma w tej ocenie Tomasza ani odrobiny przesady. Wielokrotnie mogłam utwierdzić się w tym przekonaniu, słuchając jego wystąpień na konferencjach i seminariach. Świadczyły one o gruntownej i szerokiej wiedzy praktycznej w zakresie resocjalizacji. Tomasz z dużą swobodą i znawstwem prezentował analizowane zagadnienia. Był otwarty na uwzględnianie perspektyw ugruntowanych w stricte teoretycznych dyscyplinach pedagogiki, związanych z antropologią filozoficzną, aksjologią i teleologią, choć zazwyczaj odwoływał się do podstaw pedagogiki nie wprost, były one zawarte w strukturze jego wypowiedzi w sposób domyślny (implicite). Cieszyłam się, że w gronie pracowników jest tak kompetentna osoba, którą studenci darzą wielkim szacunkiem. Nie zauważyłam, aby Tomasz wynosił się nad innych z powodu swoich osiągnięć zawodowych i naukowych. Kiedyś na zebraniu pracowników, gdy Pani Dyrektor [Alina Ryni] mówiła o podwójnym doktoracie koleżanki z Katedry Pedagogiki Rodziny, dopowiedziałam, że Tomasz Wach również ma doktorat z socjologii i pedagogiki, krótko potwierdził ten fakt bez szerszego opowiadania o tym.

Po odejściu ks. dra Zbigniewa Iwańskiego miałam okazję krótko rozmawiać z Tomaszem o powierzonych po ks. Iwańskim zajęciach, seminarium licencjackim i nowych zadaniach. Był przejęty odpowiedzialnością i okazywał pewne zakłopotanie z powodu nieprzyjemnych okoliczności nieprzedłużenia zatrudnienia ks. Iwańskiemu. Przekazałam pośrednio Księdzu, że Tomasz nie jest zadowolony z przydzielenia mu zajęć prowadzonych dotychczas przez Księdza i z pewnością wolałby kontynuować współpracę w szerszym zespole fachowców, znających się na resocjalizacji, która wśród studentów pedagogiki KUL była jedną z bardziej atrakcyjnych specjalności.

Nie miałam okazji realizowania wspólnych przedsięwzięć naukowych z Tomaszem, ale szybko zauważyłam jego zaangażowanie w wydarzenia naukowe w Instytucie (w obradach Zespołu Pedagogiki Chrześcijańskiej, konferencjach organizowanych przez inne katedry itp.). Często wygłaszał referaty, uczestniczył w dyskusjach. Pamiętam obecność Tomasza na spotkaniach 
opłatkowych, wielkanocnym „Jajku”, otrzęsinach odbywających się w Instytucie i innych utrwalonych w tradycji pedagogiki na KUL-u wspólnototwórczych wydarzeniach. Myślę, że wynikało to z jego więzi z instytutem (mimo że przecież pracował też w innych miejscach) i szacunku dla KUL-u. Powiedział to na zebraniu z rektorem ks. Ziębą, po przeniesieniu instytutu na Majdanek, że KUL ma wypracowaną „markę", której nie można narażać na szwank (w domyśle przez niekorzystną lokalizację ważnego dla uniwersytetu instytutu, odbiegające od standardów warunki kształcenia itd).

Lubiłam z Tomaszem rozmawiać o pedagogice, psychologii, socjologii, choć okazji do rozmów nie mieliśmy zbyt wiele ze względu na pracę w różnych katedrach. Rozmawialiśmy o zastępowaniu „psychopatii” mniej piętnującymi kategoriami; o „wychowalności” dzieci i młodzieży z „psychopatycznym" rysem osobowości; cyrkularności przyczyn destrukcyjnych zachowań; granicach zastosowania Treningu Zastępowania Agresji; sile czynników chroniących przed ryzykownymi zachowaniami nastolatków; nowatorskich i tradycyjnych formach resocjalizacji i wielu innych tematach. Nie zdążyłam odnieść się polemicznie do poglądu ostrożnie przyjmowanego przez Tomasza, że „agresja może mieć wymiar częściowo konstruktywny, w przeciwieństwie do przemocy", jednak nie wątpię, że usłyszałabym istotne argumenty za takim stanowiskiem, a także rzeczową krytykę kontrargumentów. Mam wrażenie, że Tomasz umiał godzić nowe inspiracje z badań z dorobkiem klasycznych teorii i koncepcji, obiektywnie przez niego ocenianych i praktycznie weryfikowanych dzięki doświadczeniu opartemu na realistycznym spojrzeniu na rzeczywistość. Z pewną zazdrością patrzyłam na jego stanowczość w formułowaniu i egzekwowaniu wymagań wobec studentów, ale bez zimnego, bezdusznego rygoryzmu.

Sama doświadczyłam od Tomasza subtelnie wyrażonych oznak wsparcia, gdy straciłam pracę na KUL-u. Spotkaliśmy się przypadkiem w listopadzie $2016 \mathrm{r}$. w Katedrze Pedagogiki Opiekuńczej, podczas moich konsultacji u ks. profesora Andrzeja Łuczyńskiego. Przez chwilę rozmawialiśmy m.in. o pracy na uczelni i godzeniu rozwoju naukowego z zaangażowaniem w kształcenie studentów. Tomasz wspomniał o znajomej psycholog, która zmieniła miejsce zatrudnienia z UMCS-u na wSEi (Wyższą Szkołę Ekonomii i Innowacji). Zapytałam, na jakim etapie są jej starania o uzyskanie habilitacji. Uśmiechnął się i powiedział, że w ogóle się ta osoba o nią nie stara, wybrała rzetelne kształcenie studentów i praktykę ekspercką. 
Nie zdążyłam pogratulować Tomaszowi szczęśliwego zakończenia przewodu habilitacyjnego. Planowałam zrobić to osobiście. Wyobrażałam sobie, że powiem mu: „Tomek, jesteś wielki! Jak to zrobiłeś?”, patrząc mu w oczy. Czas, okoliczności przedwczesnej śmierci Tomasza są dla mnie dramatyczne, ale mam silne przekonanie, że jego ciężka praca nad habilitacją miała wymiar duchowy (znaczących odkryć intelektualnych, ofiarnego wysiłku) i w tym tkwi jej istotny sens, choćby po ludzku wydawało się to „ironią losu”. Mimo całego dramatyzmu odejścia Tomasza, porusza mnie do głębi świadectwo miłości do: żony, córki, mamy. Jestem wdzięczna Bogu, że spotkałam Tomasza. Pozostanie dla mnie dobrym, nastawionym na współpracę kolegą, wiarygodnym ekspertem, silnym i mądrym człowiekiem.

Wspominając Tomasza, sięgam czasami do Esejów o nadziei ks. Jerzego Szymika, w których znalazłam słowa niezwykle trafnie wyrażające moje myśli i odczucia z nim związane, choć odnoszące się do jego imiennika Księdza Tomasza zmarłego w 32 roku życia. Brzmią one następująco: „Zostaliśmy sami, bez Tomka. Jest z nami ... smutek. I jest przeogromna nadzieja. I słowa «trwalsze niż kute w kamieniu», mocniejsze niż ta śmierć: «Błogosławiony jesteś. Ciesz się i raduj, albowiem wielka jest twoja nagroda w niebie» (Mt. 5, 11-12)".

dr Anna Lendzion, Akademia im. Jana Długosza w Częstochowie

\section{Tomasz Wach - naukowiec, współpracownik, kolega}

Śp. Tomasz Wach od kilku lat pracował w Katedrze Pedagogiki Opiekuńczej, a następnie w nowo utworzonej Katedrze Pedagogiki Społecznej i Pedagogiki Opiekuńczej, dając się poznać jako doświadczony specjalista w dziedzinie resocjalizacji. Z wykształcenia był socjologiem i pedagogiem o rozległej i dobrze ugruntowanej wiedzy, którą potrafił umiejętnie łączyć z praktyką pedagogiczną, co owocowało szerokim zaangażowaniem Tomasza w działalność rożnych instytucji opiekuńczo-wychowawczych i resocjalizacyjnych oraz szeroko pojętą aktywnością dydaktyczną skierowaną do studentów różnych uczelni w kraju i za granicą. Jako specjalista w zakresie pedagogiki resocjalizacyjnej był wysoko cenionym pracownikiem Instytutu Pedagogiki kUL, otrzymał wiele pochwał, wyróżnień i nagród, zdobył również uznanie jako wysokiej klasy kurator sądowy dla nieletnich oraz ekspert w dziedzinie mediacji sądowych. Wypełnia- 
jąc te odpowiedzialne zadania, potrafił z oddaniem pochylić się nad biedą drugiego człowieka i w sposób konstruktywny przyjść mu z pomocą i wsparciem.

Tomasz był żywo zaangażowany w działania naukowe i organizacyjne Katedry Pedagogiki Społecznej i Katedry Opiekuńczej, niejednokrotnie można było liczyć na jego pomoc w sprawach dotyczących rozwiązywania problemów z zakresu spraw społecznych i resocjalizacyjnych, był również organizatorem i współorganizatorem, z pozostałymi pracownikami Katedry, wielu ciekawych inicjatyw naukowych (konferencje, sympozja, seminaria naukowe). Podczas wspólnych działań naukowo-badawczych dał się poznać jako człowiek otwarty na nowe propozycje, a zarazem umiejący łączyć w dziedzinie wychowania tradycyjne wartości z tym, co innowacyjne. Wielokrotnie w swych wypowiedziach i opublikowanych tekstach podkreślał między innymi potrzebę podnoszenia jakości kształcenia przyszłych pedagogów, wskazywał, że muszą to być ludzie o dobrze uformowanej osobowości, posiadający wiedzę i kompetencje na najwyższym poziomie, a jako kurator sądowy uwydatniał ogromne znaczenie rodziny w życiu współczesnego człowieka, zwłaszcza dzieci i młodzieży, twierdząc jednocześnie, że jej brak lub złe funkcjonowanie powoduje niepowetowane straty w integralnym wychowawcze młodego człowieka. Jego uwaga w ostatnim okresie skupiała się jednak głównie na działaniach związanych z resocjalizacją osadzonych w zakładach karnych. W tym obszarze podejmował liczne inicjatywy (indywidualnie i wspólne ze studentami resocjalizacji), nawiązując ścisłą współpracę z Centralnym Zarządem Służby Więziennej oraz Ministerstwem Sprawiedliwości.

Poza działaniami stricte naukowymi wiele czasu poświęcał na działalność dydaktyczną i społeczną, dając się poznać jako znakomity wykładowca i prelegent oraz człowiek mocno zaangażowany w rozwijanie u studentów pasji i zamiłowania do działalności wychowawczej i resocjalizacyjnej (z jego inicjatywy powstało Studenckie Koło Resocjalizacji działające w Instytucie Pedagogiki KUL). Zyskał tym samym u studentów uznanie jako człowieka o szerokiej wiedzy i wysokich kompetencjach naukowych i organizacyjnych. W kontakcie indywidualnym był człowiekiem skromnym, ceniącym prywatność, chętnie jednak wchodził w kontakt z ludźmi, ucząc się od nich swoistej mądrości życia, którą potem umiejętnie przekazywał swoim podopiecznym i wychowankom. Radość, optymizm i pogoda ducha znamionowały go na co dzień, zauważało się to zwłaszcza podczas przypadkowych i spontanicznych spotkań i rozmów. 
Jego śmierć była dla jego najbliższych współpracowników i dla każdego, kto go znał, szokiem i pozostawiła niezatarte piętno straty dobrego kolegi i utalentowanego naukowca. Tomasz pozostanie w pamięci tych, którzy spotkali go na swojej drodze życia jako znakomity pracownik nauki i zaufany kolega, który wniósł w życie wielu ludzi realne dobro i do którego doświadczenia i dorobku naukowego wielu będzie się jeszcze długo odwoływać.

ks. dr hab. Andrzej Łuczyński, kierownik Katedry Pedagogiki Społecznej i Pedagogiki Opiekuńczej

\section{¿a. Łączyła nas troska o prawdę i dobro}

Tomasz Wach, o którym tak trudno mówić i pisać w czasie przeszłym, choć od jego śmierci minęło już kilka miesięcy, zapisał się w mojej pamięci jako człowiek wyjątkowo dobry, rodzinny, życzliwy i cierpliwy. Wprost zdumiewało mnie, że jak mało który mężczyzna umiał czekać na owoce swojej niełatwej pracy. Gdy zabiegałam o jego stałe zatrudnienie w Instytucie Pedagogiki, cieszyło mnie, że łączy teorie resocjalizacji z praktyką, a przez to jest cenionym i poszukiwanym diagnostą, terapeutą i nauczycielem. Z jego obecnością w Instytucie wiązaliśmy wielorakie nadzieje. $\mathrm{W}$ czasie, kiedy nasze drogi zawodowe zetknęły się nieco bliżej, dał się poznać jako bardzo troskliwy syn, przy boku którego jego przedwcześnie owdowiała i wiekowa już mama (Tomek był jedynakiem) chciała dożyć swoich dni, a przy tym dał się też poznać jako troskliwy i wyjątkowo odpowiedzialny mąż i ojciec, lojalny pracownik i kolega.

Tomasz był człowiekiem kochającym życie, drugiego człowieka, a szczególnie ludzi młodych, którzy z różnych powodów wchodzili na drogę przestępczą i znajdowali się $\mathrm{w}$ wielorakich potrzebach. Przez wiele lat był poszukiwanym diagnostą orzekającym w sprawach dla nieletnich i sprawował kuratelę sądową, co wymagało nie tylko kompetencji, ale również cierpliwości i sztuki wymagania, stawiania granic, a niekiedy mówienia nie. Wymagał najpierw od siebie, i to bardzo wiele, a dopiero potem od innych. Zawsze dużo pracował i umiejętnie godził życie zawodowe i rodzinne. Kochał swoich najbliższych i studentów. Postrzegałam go jako człowieka o wielkim sercu, który mało mówił, dużo obserwował i potrafił słuchać jak mało kto na świecie. Był przy tym człowiekiem sprawiedliwym, skromnym i pracowitym. Równocześnie dał się poznać jako ktoś, kto jest oddany swojej pracy, która stała się dla niego pasją i motorem do dzia- 
łania. Umiał podejmować różne trudne wyzwania, kierując się bardziej dobrem wspólnym niż własną wygodą. Traktował innych z godnością i w sposób podmiotowy. Kochając prawdę bardziej niż samego siebie, nie pozwolił przy tym sobą manipulować, czego byłam świadkiem i powiernikiem. Miał swoje zdanie i dokonywał trudnych wyborów. Dzieląc się swoimi doświadczeniami, bez nadmiernej wylewności potrafił podjąć ryzyko i podać pomocną dłoń osobom pozostającym w tarapatach życiowych. Niejednokrotnie byłam zbudowana jego postawą jako męża, ojca, kuratora i młodszego kolegi. Dlatego też jego nagłe odejście przyjęłam z wielkim bólem i niedowierzaniem. W jednym momencie przewinęły się przed oczami wszystkie ważne sprawy, spotkania i słowa. Mając ciągle w pamięci nagłą śmierć mojego ukochanego brata, pomyślałam o Jego najbliższych i ich bólu rozstania. Jestem przekonana, że długo będzie im i nam Ciebie, Drogi Tomku, brakowało. Równocześnie wiem, że Pan Bóg na moment naszej śmierci wybiera chwilę najstosowniejszą i trudno odpowiedzieć, dlaczego nie jest Ci dane dłużej pozostawać wśród żywych, wśród których byłoby jeszcze tak wiele do zrobienia. Dlatego z pokorą chylę głowę przed słowami Miguela Maniary, z dramatu Oskara Miłosza, że ostatecznie „wszystko zmierza do kresu znaczonego mądrością, która nie jest nasza”. Z doświadczenia wiem też, że „po to jest pamięć, by żyła obecność". I w duchu tej pamięci zechcę sięgnąć po ostatnią Twoją książkę, będąca podstawą habilitacji przyznanej Ci na kilka dni przed Twoją śmiercią. Twoich najbliższych zapewniam o trwałej pamięci w modlitwie, a Ciebie proszę o wstawiennictwo, abyśmy pozostali wierni prawdzie i wielorakiemu dobru, którym całym życiem służyłeś.

dr hab. Alina Rynio, prof. KUL - kierownik Katedry Pedagogiki Chrześcijańskiej

\section{Go Gdzie cierpienie, tam znajdziesz łaskę pod różną postacią}

W dniach żałoby po nagłej śmierci śp. Tomasza Wacha w dniu 28 grudnia $2016 \mathrm{r}$. czytałem powieść Williama P. Younga pt. Chata. Jest to wzruszająca historia o tym, jak Bóg przychodzi do nas, gdy jesteśmy pogrążeni w głębokim smutku. Stajemy się wtedy niewolnikami własnych oczekiwań, a nawet czujemy się wręcz zdradzeni. Wskazuje na to już pełny tytuł książki Chata. Gdzie śmierć zderza się z wiecznością (tłum. A. Reszka, Warszawa 2011). Jej treść daleka jest od religijnych komunałów. 
Cierpiącemu ojcu po nagłej i tajemniczej stracie córki Bóg powiedział w spokojnym dialogu: „Łaska nie zależy od cierpienia, ale tam, gdzie jest cierpienie, znajdziesz łaskę pod różną postacią” (s. 206). Stwórca dodał jeszcze: „Chcę śmierć, zagubienie i ciemność przemienić w życie, wolność i światło. [...]. Wszystko musi się stopniowo rozwinąć, nawet jeśli tych, których kocham, spotykają potworne tragedie, jeśli nie omijają najbliższych mojemu sercu" (s. 212-213).

W powieści jest mowa także o tym, że prawdziwa miłość nigdy nikogo do niczego nie zmusza. Nawet pojednanie między ludźmi nie może być narzucone, ale musi wynikać z dążenia każdej z jednających się stron do szukania i znajdywania wspólnej drogi. A cierpienie pomaga do zjednoczenia serc, zdolnych do wspólnego odczuwania tego, co raduje, ale i do tego, co smuci.

Myśl przewodnia tej niezwykłej książki streszcza się w przekonaniu, że Jezus przebędzie każdą drogę, żeby człowieka odnaleźć.

Bohater książki, jak podpowiadała autorowi wyobraźnia, spotykał się z Bogiem w sposób niezwykły. Stanął przed zadaniem bardzo trudnym, wymagającym, gdyż Bóg nie jest łatwym rozmówcą. Toteż człowiek wyszedł z tego dialogu obolały, ale zarazem przekonany, że tylko energia w szukaniu wartości wskazanych przez Stwórcę, walka o nie z radosną nadzieją na zwycięstwo, nadaje wszystkiemu sens. Energia ta była też dla niego źródłem niespotykanego spokoju, jakiego dotąd nigdy nie doświadczył. Dostrzegł w tym pełne uwolnienie od cierpienia, które absorbowało całe jego jestestwo.

Chata napisana jest dla dzieci i im została dedykowana. We wstępie uderza inna niezwykła dedykacja. „A po drugie: «wszystkim nam, błądzącym, którzy wierzą, że Miłość rządzi. Wstańcie, pozwólcie jej jaśnieć»”.

Może tych kilka myśli pomoże ogarnąć jakoś to wszystko, co z bólem przeżywamy od dnia nagłej śmierci tak bardzo nam bliskiego śp. Tomka Wacha, pedagoga. Był wielką nadzieją, mierzoną planowaną pracą, zdolnościami, ugruntowanym, jak można było sądzić, miejscem w środowisku, w które wrósł całą swą osobowością, pełnym zapałem służenia nie tylko młodzieży, ale także nam wszystkim, którzyśmy wiedzieli, czego możemy się po nim spodziewać.

Stało się inaczej. Dlaczego? Mamy prawo stawiać to pytanie, a Bóg planujący dzieje świata i los każdego człowieka z pewnością podsunie kiedyś odpowiedź. Zapewne zdumienie nas ogarnie, jakże ona jest prosta. Bo tak działa Boża Opatrzność!

ks. prof. dr hab. Edward Walewander, kierownik Katedry Pedagogiki Porównawczej 


\section{Zawsze gotowy do pomocy i otwarty na wspólne działanie}

Dr hab. Tomasz Wach odszedł tak nagle i niespodziewanie, że kiedy dowiedziałem się o Jego śmierci, myślałem, że to zły sen. Sądziłem, że obudzę się następnego dnia, a to wszystko okaże się tylko koszmarnym sennym. Niestety tak nie było.

Tomasza znałem od 2009 r., kiedy przyszedłem do pracy w Instytucie Pedagogiki (dalej IP). Pierwszy taki kontakt został nawiązany przy pisaniu książki o IP. Napisał wówczas swój biogram, ale okazało się, że nie jest etatowym pracownikiem i nie został on umieszczony. Kilka razy prosiłem go o zdjęcie do biogramu, ale czułem, że Tomasz nie za bardzo chce go dać.

Przez następne lata widywaliśmy się na korytarzu, na opłatku, jajku, konferencjach, wyjazdach integracyjnych w Kazimierzu Dolnym. Od 2013 r. nasze kontakty nasiliły się, ponieważ byłem zastępcą dyrektora IP KUL, często prosiłem pracowników o pomoc w organizacji różnych przedsięwzięć w IP. Wśród tych osób był dr Tomasz Wach. Nigdy nie odmawiał, ale pytał tylko „na kiedy?", żeby wygospodarować czas. Brał udział w Dniach Otwartych IP na Majdanku, angażował się w tworzenie nowego kierunku pedagogiki resocjalizacyjnej, przy którym pracowaliśmy razem z ówczesną prodziekan prof. Iwoną Niewiadomską, ks. Andrzejem Łuczyńskim i pracownikami z IP. Był uczynny i zaangażowany maksymalnie w to, co robił. Nie uznawał fuszerki lub markowania wykonywanych prac. Dobrze mi się z nim współpracowało, gdyż ceniłem takie Jego podejście do pracy oraz Jego znaną wszystkim punktualność, czego tu, na Wschodzie, nie zawsze da się wyegzekwować od innych.

Tomasz zaangażował się również w tworzenie i powstanie książki w serii mojej Katedry „Biblioteka Katedry Biografistyki Pedagogicznej”: Wzory i wzorce osobowe w biografistyce pedagogicznej, red. R. Skrzyniarz, M. Gajderowicz, T. Wach, Lublin 2013.

Nigdy o sobie nic nie mówil, nie użalał się, nie chorował, zawsze twardy, stanowczy, zdecydowany, stonowany, uśmiechnięty, kiedy ku temu była okazja. Dowiedziałem się, że gdy Tomasz był w trzeciej klasie szkoły podstawowej, zmarł mu Tato. Matka wychowywała go sama. Rodzina często borykała się z biedą. Tomasz do tego, co osiągnął w życiu, doszedł systematycznością, niejednokrotnie wyrzeczeniami i konsekwencją. Z opowiadań Jego żony Jolanty dowiedziałem się, że Tomasz tylko raz w swoim życiu opuścił szkołę na trzy dni, gdy był chory na wietrzną ospę. Ta obowiązkowość i punktualność pozostała w Jego życiu bardzo ważna i nadawała ton jego pracy i kontaktom z innymi osobami. 
W mroźny i z przebłyskami słońca dzień Jego pogrzebu, gdy karawan podjechał pod drzwi kościoła św. Agnieszki zobaczyłem trumnę z ciałem, zalałem się łzami - nie tylko ja. Nieopodal mnie stała Jego Mama, osiemdziesięciokilkuletnia, drobna, niska kobieta zalana łzami z grymasem nieopisanego bólu matki, która żegna swoje jedyne dziecko. Przyszedłem pożegnać się z Tomkiem - nie na długo, bo niebawem znów spotkamy się, ale już w domu naszego Boga Ojca. Ty tam już jesteś i czekasz na nas. Wspieraj nas swoją modlitwą przed tronem Ojca. „Wieczny odpoczynek racz Mu dać Panie”.

dr hab. Ryszard Skrzyniarz, prof. KUL, kierownik Katedry Biografistyki Pedagogicznej

\title{
Studenci
}

20 Pan dr hab. Tomasz Wach uczył nie tylko resocjalizacji, ale również życia. Często powtarzał: „Jeżeli nie wiesz, jak coś zrobić - zacznij to robić”. W trudnych dla mnie chwilach przypominam sobie te słowa i wcielam je w życie. Zawsze pomaga i dodaje odwagi.

Katarzyna Szabała, pedagogika specjalna, I rok II stopień

\begin{abstract}
60 „Systemowość" to termin, który śp. Pan Tomasz wałkował nam do znudzenia przez wszystkie lata nauki. Każdy wiedział, że jeśli ma coś do powiedzenia, musi powołać się na konkrety, żadne lanie wody z głowy nie przejdzie. Nie był taki straszny, na jakiego z pozoru wyglądał. Miał poczucie humoru, które momentami wyrywało z butów. Ah, te jego opowieści jak to „księżniczka mówi do księcia..."! Cenił myślenie. Nie chciał suchych regułek. Czekał na fakty, odwołania do rzeczywistych sytuacji, praktyki. Jedyne czego jestem pewna poza tym, że w naszych głowach i sercach pozostanie zawsze jako najlepszy wykładowca praktyk, to fakt, że każdy z grupy resocjalizacji obudzony w nocy o północy powie, a nawet wyśpiewa z dumą, kim jest nieletni, małoletni i młodociany! I za wszystko wszyscy serdecznie mu dziękujemy!
\end{abstract}

Paulina Fąara, rok II stopień II

Śp. Pan Tomasz był człowiekiem z poczuciem humoru, które często było
trafione w daną sytuację i w dany punkt. Wszystko, co było mówione, musiało
być argumentowane co, jak i dlaczego?, a np. dlaczego nie tak? Był człowiekiem 
o wielkim sercu i o jeszcze większej wiedzy, którą przekazywał nam w 10000\%. Wszystko, co mówił i jak przekazywał wiedzę, było oparte na jego doświadczeniu i ciężkiej pracy. Zawsze będziemy o Nim pamiętać i dziękujemy za wszystko Aleksandra Ciorgoń, rok III stopień I

20 Może nie z zajęć, ale ze spotkań na korytarzu „majdankowym”, jeżeli się z nim przywitało, zawsze odpowiadał z uśmiechem na twarzy $;$, pogodny człowiek z wielką energia $:-$. Kiedyś, czekając na zajęcia, udało mi się z nim zamienić kilka słów i bardzo miło to wspominam. Rozmowa, mimo że krótka w pamięci została. Patrząc na Tomasza Wacha, widziało sie osobę, która ma pasję i chce ją przekazać innym. Był lubiany przez studentów zarówno tych, których uczył, i tych, z którymi mijał sie na „majdankowych” korytarzach.

Katarzyna Marcinek, rok II stopień II

60 Tomasz Wach: zero spóźnienia (:) zaczynamy 8.20 i tak zamykają się drzwi (:) - punktualność to cecha, której mega przestrzegał sam i wymagał od innych. Milena Welc, II rok II stopień

6. Pan dr Tomasz Wach zawsze gotowy był, aby nas rozwijać.

Izabela Caboń

So śp. prof. Tomasz Wach był zarówno bardzo dobrym teoretykiem, jak i praktykiem. Na studiach pedagogicznych czy psychologicznych potrafił namacalnie, dynamicznie, z wielką pasją ukazać nam, czym jest resocjalizacja. Nie tylko mówił, ale mobilizował nas do myślenia (rozważania), zadawał pytania - aktywnie, słuchał. Zajęcia były prowadzone w formie konwersatorium, w których każdy uczestniczył czynnie z wielkim zaangażowaniem. Przeplatane z poczuciem humoru i anegdotami były takie radosne i jednocześnie po prostu ludzkie (otwarte na drugą osobę - studenta)...

Jako już doktorantka dostrzegłam śp. prof. T. Wacha jako człowieka bardzo skromnego, pomocnego, wyważonego, uważnie słuchającego. Jego wystąpienia były zawsze interesujące, wabiły swą uwagą, oparte na bardzo dużej wiedzy, które współgrały z bogatym doświadczeniem.

Ilona Gumińska-Sagan, absolwentka pedagogiki i psychologii, doktorantka KUL 
20. Pan Profesor Wach był nie do zdarcia. Na zajęciach nie było go tylko wtedy, gdy organizowana była jakaś ważna konferencja. Wtedy też zachęcał studentów resocjalizacji do wzięcia w niej udziału, listy obecności zawsze były nietuzinkowe - każda miała inny kolor, organizował wyjazdy do więzienia w Opolu Lubelskim i Aresztu Śledczego w Lublinie, chcąc pokazać nam przyszły zawód od podszewki. Zawsze ze zrozumieniem podchodził do studentów i cenił sobie kontakt z nimi.

Joanna Kruk, rok I, II stopień

So Śp. Pan Profesor Wach był człowiekiem o wielkim sercu, z pasją i zaangażowaniem przekazywał wiedzę, nie zaglądając w kartkę. Z wielką życzliwością i zainteresowaniem troszczył się o każdego z Nas. Dbał o swoje sprawy i tego uczył Nas wszystkich. Zarażał uśmiechem, dobrym słowem, nawet żartem. Był i będzie niezastąpiony.

Karolina Wach, rok I, II stopień

12 Prawdziwy mentor... Ze 100\% pewnością stwierdzam, że gdyby nie szeroki zasób wiedzy dr hab. Tomasza Wacha, jego ciekawa osobowość, zamiłowanie do resocjalizacji i profesjonalizm, nie byłabym teraz w tym miejscu, w którym obecnie się znajduję - jeżeli chodzi o wybór ścieżki zawodowej. Pamiętam, że spora część grupy resocjalizacyjnej już po pierwszych zajęciach wykruszyła się, „obawiając" się (-) o przetrwanie na tej specjalizacji, kiedy dr hab. Tomasz Wach „nakazał" przeczytać cały Kodeks karny, Kodeks karny wykonawczy itd. :) Oczywiście, zawsze powtarzał, że tak samo jak w przypadku polecanych przez Niego książek, przeczytają je ci „najlepsi”. W pewnym sensie można uznać to za bardzo budujące...

Spóźnianie się? Nie ma mowy! Tak jak napisała Milena, wybija konkretna godzina, drzwi zamknięte, coś w stylu: „10 sekund po czasie wchodzisz na własne ryzyko" - oczywiście żartobliwie. :) Jedna z koleżanek (a może to byłam nawet ja? - nie pamiętam dokładnie) „wtargnęła” do sali i zaczęła przepraszać za spóźnienie, a Pan dr hab. Tomasz Wach, patrząc na zegarek, powiedział: „Ale nie

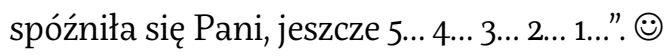

Wydawał się być takim „twardym zawodnikiem”, nieugiętym, stanowczym, pewnym siebie, choć może i takim był, ale na pewno posiadał w sobie wiele ciepłych, pozytywnych cech. Ciężko było zauważyć u pana dr hab. Tomasza 
Wacha uśmiech. Strasznie go skrywał! Mojej dawnej grupie jednak udawało się czasami ten uśmiech jakby „wyegzekwować”. :)

Cóż więcej? Dawał z siebie maksimum, choć przyznaję - na samym początku „starcia” ze specjalizacją resocjalizacyjną ciężko było zrozumieć terminologię stosowaną przez dr hab. Tomasza Wacha, ale zawsze zaznaczał, żeby posługiwać się „specjalistycznym słownictwem” - to ważne, naprawdę ważne. Z perspektywy czasu doskonale wiem, jak bardzo teraz to słownictwo jest przydatne.

Dlatego też osobiście wiele zawdzięczam śp. dr hab. Tomaszowi Wachowi. Trzeba przyznać również, że był bardzo pamiętliwy! Poświęcał swoją uwagę, dopytywał o plany życiowe, a przede wszystkim nie pozwolił na to, żeby się poddawać, a uparcie dążyć do wyznaczonych sobie celów.

Jego brak to ogromna strata.... Strata wspaniałego pedagoga, praktyka, mentora, a przede wszystkim takiego samego jak każdy z Nas - człowieka, o tych wszystkich wspaniałych, dobrych i życzliwych cechach.

Jan Paweł II mówił, że: „Człowiek jest wielki nie przez to, co posiada, lecz przez to, kim jest; nie przez to co ma, lecz przez to, czym dzieli się z innymi". O „wielkości” śp. dr hab. Tomasza Wacha świadczy właśnie to, kim on był i jak znaczącym dorobkiem, wspaniałymi wartościami i mądrym słowem dzielił się z innymi - Nami studentami.

Anna Błaszczyk, II rok, II stopnia

6. Pan Profesor Tomasz Wach był wspaniałym wykładowcą i fantastycznym człowiekiem. Choć przy pierwszym spotkaniu wydawał się być ostry i nieugięty, być może nawet „zimny”, to z każdym następnym okazywało się, jak ważni są dla niego studenci i jak bardzo troszczy się o to, abyśmy „poczuli” resocjalizację abyśmy zapałali do niej taką samą pasją, jaką miał Pan Profesor. Zawsze dawał z siebie 100\%, jednak nigdy nie prowadził nas, studentów, za rękę, dawał nam wędkę, ale nie rybę. Wymagał od siebie, ale też od nas. Przy tym był rozbrajająco szczery. Pan Profesor wspaniale przeplatał wiedzę teoretyczną z informacjami praktycznymi, przez co sprawiał, że na jego zajęcia przychodziło się z przyjemnością i ciekawością, a gdy ich nie było, odczuwało się swego rodzaju niedosyt.

Dostrzegał w swoich studentach to, czego oni sami nie widzieli i umiał ich motywować. Miałam to szczęście, że Pan Profesor Tomasz Wach był promotorem mojej pracy licencjackiej. I muszę przyznać, że to było moje największe szczęście, jakie mogło mnie spotkać. Pomimo wyjątkowego tematu mojej pracy 
licencjackiej Pan Profesor, doskonale wiedział jak mną pokierować, aby zamierzony cel został osiągnięty. Zawsze był do naszej dyspozycji, wypożyczał nam swoje prywatne książki i widać było, że czuł się odpowiedzialny nie tyle za to, żebyśmy te prace napisali, żebyśmy napisali je z satysfakcją. Do dziś pamiętam, jak miałam problem z napisaniem jednego z podrozdziałów mojej pracy. Zapytałam wtedy Pana Profesora Wacha, czy mogłabym po prostu wykreślić ten podrozdział i zająć się dalszym pisaniem. I co wtedy odpowiedział Pan Profesor? „Pani Agnieszko, nie wolno oddawać walki walkowerem. Dopóki nie leżymy na łopatkach, walka trwa". Nie pomogło moje dalsze przekonywanie, Pan Profesor trwał przy swojej racji. Kilka tygodni później napisany podrozdział leżał na biurku, choć sama nie mogłam uwierzyć, że mi się udało. A zdanie, które wtedy usłyszałam, choć tak proste i wydawać by się mogło banalne, ja powtarzałam sobie za każdym razem, gdy napotykałam jakąś trudność. Praca została napisana 1,5 miesiąca przed ostatecznym terminem oddania, byłam z niej bardzo dumna, właściwie do teraz jestem dumna, a wszystko to zasługa Pana Profesora Wacha.

Dobry Bóg oprócz spotkań na zajęciach pozwolił mi współpracować z Panem Profesorem przy projekcie prowadzonym w ramach Koła Resocjalizacji, którego był opiekunem, a także przy organizacji dwóch konferencji naukowych. Mimo ciężkiej pracy i pojawiających się wątpliwości, czy sobie poradzę, zawsze był ktoś, kto wierzył, że jest dobrze, a będzie jeszcze lepiej - to był właśnie Pan Profesor. Z anielską cierpliwością Pan Profesor Wach odpowiadał na moje pytania, sprawdzał przygotowany materiał, uspokajał i motywował do dalszej pracy, pokazując mi jednocześnie, jak wykorzystywać to, czego się nauczyłam w praktyce. Dziś wiem, że mogę powiedzieć o śp. Panu Profesorze, że był moim mistrzem.

Pan Profesor Tomasz Wach bez wątpienia odmienił moje życie. Ciężko ubrać w słowa to wszystko, co mam w sercu i głowie, choć starałam się opisać jak najwięcej z tego, co już na zawsze we mnie zostanie. Pan Profesor Wach wiele mnie nauczył i pokazał, jak wykorzystywać to, co umiem, w swoim życiu zawodowym. Myślę, że wielu studentów i byłych studentów również może powiedzieć to samo. Stawiał wysokie cele, jednak takie, które wspólnie z nim mogliśmy osiągnąć. To człowiek, dzięki któremu zapragnęłam być pedagogiem, dzięki któremu pokochałam resocjalizacje, dzięki któremu wiem i potrafię o wiele więcej niż kiedykolwiek. Pedagogika doznała nieodżałowanej straty. 
Panie Profesorze, Bóg jeden raczy wiedzieć, jak wiele Panu zawdzięczam. I za to wszystko mogę jedynie powiedzieć: dziękuję. Bieg ukończony, proszę odpoczywać w pokoju i do zobaczenia po tej lepszej stronie.

Agnieszka Morska, absolwentka - studia na stopniu I i II w latach 2011-2016

20 Pojedynki na spojrzenia, które zawsze kończyły się radosnym uśmiechem jednej i drugiej strony; silny charakter, który nie górował nad studentem, a raczej zapraszał i skutecznie zachęcał do pracy nad sobą; wspaniałe poczucie humoru, które niekiedy przyozdabiała przemyślana, delikatna ironia, nie po to, żeby zadrwić, ale raczej po to, aby zachęcić do myślenia - takim zostanie zapamiętany przeze mnie prof. Tomasz Wach. Pedagog w pełnym tego słowa znaczeniu, który określając konkretne zasady, pokazywał, że nad własnym charakterem trzeba pracować. Szczery, pogodny, okrutnie konkretny i bardzo otwarty wychowawca akademicki. Nie tylko kształcił, ale po mistrzowsku towarzyszył swoim studentom.

Panie Profesorze! W dobrych zawodach wystąpiłeś, bieg ukończyłeś i wiary ustrzegłeś! Uśmiechaj się do nas z Ojca domu! Dziękujemy!

Małgorzata Karpińska, II rok, II stopień

Sóp. dr hab. Tomasz Wach zarówno na licencjacie, jak i obecnie na studiach magisterskich wywierał duży wpływ na studentów. Zdecydowany, duży mężczyzna, profesjonalista w swojej dziedzinie, który zawsze zażartował - tak go zapamiętam. Zajęcia prowadzone w interesujący sposób, egzaminy u niego zawsze były prawdziwą przyjemnością. Śmierć przyszła za szybko, do dzisiaj pamiętam słowa dra Wacha z naszego ostatniego grudniowego spotkania: „wpisy będą w styczniu". Niestety, nie dane nam to będzie, jednak zawsze będę pamiętać tak wybitną postać, jestem dumna, iż dane mi było być jego studentką.

Aneta Gąbla

20 zép. dr hab. Tomaszem Wachem miałam tylko jeden wykład (Pedagogika resocjalizacji na 2 roku 1 stopnia). Wykłady z profesorem były dla mnie jako studentki pedagogiki wczesnoszkolnej i przedszkolnej bardzo interesujące. Przekazywał nam wiedzę, opowiadając różne sytuacje losowe, tak abyśmy mogli lepiej zrozumieć często bardzo dotkliwe problemy. Zarażając zainteresowaniem do resocjalizacji, podkreślał, jak ważne jest wychowanie już od najmłodszych lat 
(etap przedszkolny i wczesnoszkolny). Dzięki profesorowi mogłam uczestniczyć razem z grupą resocjalizacji w organizowanym w 2016 roku wyjściu do aresztu śledczego w Lublinie, za co jestem bardzo wdzięczna. Wykłady i sam sposób bycia śp. dra hab. Tomasza Wacha zostaną mi na długo w pamięci.

Wioletta Wójcik, studentka pedagogiki III rok I stopnia

6. Październik 2009 - pierwsze zajęcia w roku akademickim były właśnie z panem drem Tomaszem Wachem. Od razu dał się poznać jako otwarty na innych ludzi człowiek, szybko zjednał sobie sympatię moją oraz kolegów i koleżanek z grupy. Z czasem dał się poznać jako człowiek o wielkiej wiedzy i doskonały praktyk. I choć czasem mieliśmy z panem drem odmienne zdania co do młodzieży z mojego osiedla, to i tak darzyłam go wielkim szacunkiem. Nieraz widziałam go idącego ulicą Łęczyńską w Lublinie, podczas wykonywania swoich obowiązków kuratora społecznego. Oddany był i pracy na uczelni, i pracy społecznej. Niewiele osób jest do tego zdolnych. Będzie brakować pana dra w Instytucie Pedagogiki - to pewne, ale i tak zapisał się na zawsze w sercach i umysłach swoich studentów i studentek.

Renata Makarewicz, absolwentka

20 Pana profesora Tomasza Wacha nie znałam długo, jedynie około półtora roku. Jednak wszystko to, co po nim we mnie zostało, nie odzwierciedla tego czasu. Tomasz Wach to człowiek, który swoją wiedzą, doświadczeniem, przykładem życia, podejściem do studenta, pasją, charakterem, sprawił, że tematyka kryminologii, terapii w resocjalizacji i innych zagadnień związanych z moją specjalizacją, zaczęły naprawdę mnie interesować. Zupełnie pochłonął mnie sposób prowadzonych zajęć przez pana Tomasza, jego poczucie humoru, uśmiech, precyzja, to tylko niektóre z cech, które bardzo sobie w nim cenię.

$\mathrm{Na}$ zajęcia, które prof. Tomasz prowadził, przychodziłam z przyjemnością i z zaciekawieniem słuchałam wszystkiego, co chciał nam przekazać. Nie przesadzę, jeśli powiem, że dla mnie stał się Przyjacielem. Nie był to zwykły wykładowca. To człowiek o wielkim sercu, świetnym sposobie bycia. Z nim aż chciało się mieć zajęcia. Zabierał nas w różne miejsca, wymagał i uczył. Naprawdę uczył. Na żadnych innych zajęciach nie zdobyłam takiej wiedzy, jak na zajęciach prof. Wacha. 
Śp. Tomasz Wach był bardzo otwarty na propozycje studentów. Dużo z nami planował, mieliśmy razem zrobić jeszcze wiele...

Osoba śp. prof. Tomasza pozostanie w mojej pamięci i sercu do końca mojego życia. Jestem wdzięczna dobremu Bogu, że postawił takiego człowieka na mojej drodze, że mogłam go poznać. Dla mnie osobiście to nieoceniony dar. Jestem pewna, że prof. Tomasz Wach jest już w niebie, patrzy na nas, początkujących pedagogów, wspiera i nam towarzyszy.

Słowa nie są w stanie opisać tego, co czuje moje serce. Odejście z tego świata pana Tomasza to ogromna strata dla każdego, kto docenia to, co zrobił w swoim tak krótkim życiu.

Niech spoczywa w pokoju. Na zawsze w mojej pamięci.

Joanna Pąk, pedagogika specjalna, specjalność resocjalizacja, II rok, stopień II

Tomasz Wach dość długo był w katolickim harcerstwie „Zawisza” - tak wspomina jego żona Jolanta. „Dało mu ono wiele umiejętności i wytrwałości, poznał tam wiele osób, z którymi utrzymywał znajomości". Próbowałem dotrzeć do osób, które go znały, ale ludzie ci już niewiele pamiętali. Ktoś mi tylko wspomniał, że pamięta Go jako "małego blondynka zbuntowanego przy kajaku”. Być może ktoś z czytających te słowa lepiej Go pamięta i byłby w stanie więcej o tym okresie Jego życia powiedzieć.

Zawarte tu wspomnienia nie zamykają pamięci o Tomaszu Wachu. Można nadsyłać swoje wspomnienia, które posłużą do lepszego poznania i zapamiętania naszego niezapomnianego Kolegi i Nauczyciela. 